\title{
Effects of Organizational Culture on the Performance of Africa Inland Church Theological Training Institutions in Kenya
}

\author{
Munyao, Solomon. M. , Chiroma ${ }^{1}$, Nathan. H. (PhD) \& Ongeti ${ }^{2}$, Walter. J. (PhD) ${ }^{3}$ \\ ${ }^{1}$ School of Leadership, Business and Technology, Pan Africa Christian University, P.O. Box 56875-00200, Nairobi \\ ${ }^{2}$ School of Theology, Pan Africa Christian University, P.O. Box 56875-00200, Nairobi \\ ${ }^{3}$ School of Leadership, Business and Technology, Pan Africa Christian University, P.O. Box 56875-00200, Nairobi
}

DOI: 10.29322/IJSRP.10.03.2020.p9940

http://dx.doi.org/10.29322/IJSRP.10.03.2020.p9940

\begin{abstract}
The primary goal of missionaries at the time of coming to Africa was to spread the gospel and establish churches for those who were converting to Christianity. For Africa Inland Church (A.I.C), the first missionaries initially established mission stations in Machakos with other stations being opened soon after in Central Kenya and Rift Valley respectively. The rapid growth of the number of people who were converting to Christianity and the many churches that were being opened required leaders to run them. This made missionaries to start Ukamba Bible School as the first A.I.C theological training institution in Machakos with Moffat Bible School being opened soon after in Kijabe. However, despite the repaid growth of the theological training institutions, very little research studies had been carried out to determine the factors affecting their performance. The aim of this study was therefore to establish the effects of organizational culture on the performance of A.I.C theological training institutions in Kenya. The study employed a descriptive survey research design with closed and open ended questionnaires being used to collect data from 120 Management members, employees and third year students. The results indicated that organizational culture had a positive correlation with performance at 0.517 with 26.7 percent of organizational performance in A.I.C theological training institutions being explained by organizational culture with the remaining 73.3 percent being explained by other variables. The significance of the model between organizational culture and organizational performance was statistically significant with an Fvalue of 33.475. Both $p$-value and $\beta$ value were 0.517 indicating that organizational culture has both significance and effect on organizational performance.
\end{abstract}

Index Terms- Strategic leadership, organizational culture, organizational performance.

\section{INTRODUCTION}

$\mathrm{T}_{1}$ he first Africa Inland Mission (A.I.M) missionaries who came to Kenya mostly from America and European countries started theological training institutions in order to train adequate and qualified church leaders to cater for the growing congregation. Their first stations were in Ukambani where they also established the first Africa Inland Church (A.I.C) theological training institution. After they had established Ukamba Bible School in
Machakos, they there soon after started Moffat Bible Institute in Kijabe. However, despite the rapid growth of A.I.C theological training institutions, they were still faced with various challenges such as culture that Mumo (1997) mentioned as being not receptive of new development ideas. It is for this reason that his study sought to establish the effects of organizational culture on the performance of A.I.C theological training institutions in Kenya. The elements of organizational culture that were discussed in this study are organizational values, policies and procedures, workplace climate, employee engagement, reward system, and stakeholder engagement.

\section{Statement of the Problem}

Although on the onset, organizations are started for the purpose of achieving set objectives, previous research studies had pointed out that majority of them fell short of this expectation. According to Mumo (1997), Nkonge (2013), Naidoo (2015) and Ng'ang'a (2018), several organizations have been undergoing performance challenges for some time now due to various reasons. For example, after the opening of many A.I.C theological training institutions was done without proper planning since each Regional Church Council wanted to have one of its own (Mumo, 1997), many of them found themselves not able to attract the required number of students to financially sustain them besides of donor funding, poor utilization of resources, resistance to change and styles of leadership. Despite the performance challenges that have been facing A.I.C theological training institutions in Kenya, little research had been in the past to establish the same. In fact, majority of previous research on the effects of organizational culture on performance had mostly been done in secular organizations and mostly in developed countries (Ng'ang'a, 2018). This is the problem and gap that this research study sought to fill.

\section{ORganizational CUlture}

Organizational culture is one of the aspects of strategic leadership that determine how successful or unsuccessful an organization will be. Volberda, Morgan, Reinmoeller, Hitt, Ireland and Hoskisson (2011) defined it as a complex set of ideologies, 
symbols and core values that are shared throughout a firm and that influences how the firm conducts business it is involved in. Sudarsanam (2010) posited that organizational culture determines how a firm's stakeholders are treated resulting in some level of performance. On their part, Ivancevich, Konopake and Matteson (2014) explained organizational culture as what employees perceive and how this perception creates a pattern of beliefs, values and expectations. Additionally, Naidoo (2016) cited institutional culture as one of the most salient forces operating in higher education because it is a vehicle for implementing organizational and institutional change. The role of organizational culture is so important in the performance of organization such that without cultural nurturing, organizations will be unable to produce results that are sustainable and will lack a lasting competitive advantage (Ng'ang'a, 2018). Organizational culture can manifest itself in organizational values, policies and procedures, workplace climate, employee engagement, reward system, and stakeholder engagement.

\subsection{Organizational Values}

Cram (2012) defined organizational values as the specific dimensions that represent manifestations of the culture and beliefs of an organizational group. Distinct from the values associated with a national culture such as power distance, uncertainty avoidance, organizational values are directly associated with a specific organizational setting such as business unit or work group. Quennevvile, Bentein and Simard (2010) cited organizational values are a relevant field of study because they influence various organizational dimensions including employee commitment, job satisfaction (Kumar, 2012), business ethics (Suar \& Khuntia, 2010) and organizational culture among many others. In a previous research study, Joyce (2012) discovered that organizational purpose and values lead to employee loyalty and happiness which in turn translates to customer loyalty and profit.

\subsection{Policies and Procedures}

The success or failure of an organization is to a large extent determined by whether there are clearly laid down policies and procedures. Wolosz (2007) defined policies as clear statements of purpose that foster consistent observation of directives dictated from the board and senior management of an organization to all employees. Further, policies are generated based on the laws, regulations and industry best practices applicable to the business focus of a particular firm. Procedures are working instructions mapped to the firm's policies, tailored to cover unique requirements for a product, a country and legal entities. Memon, Panhwar, and Rohra (2010) defined policies as systems that codifies decisions established by an organization to support administrative personnel functions, performance, employee relations and resource planning. Moreover, policies provides generalized guidance on how issues should be dealt with while procedures spells out precisely what steps should be taken to deal with major issues such grievances, discipline, capability and redundancy (Armstrong \&Taylor, 2014). Previous studies had pointed out to the fact there existed a positive correlation between policies and procedures and organizational performance (Kwenin, Muathe, and Nzulwa, 2013).

\subsection{Workplace Climate}

Work climate also known as work environment that is found in an organization is a reflection of its culture. It denotes the place that one works which means the social environment around a person (Gunaseelan, 2012). Further, it is the social and professional environment in which a person is supposed to interact with a number of people. Ozge and Altindag (2016) defined organizational climate as the whole of factors which are perceived by the individuals who constitute the organization and affect their behaviors. Again, it is the processes, systems, structures, tools or conditions in the workplace that impact favorably or unfavorably individual performance. Omolayo, Owolabi, Omole, and Ekundayo (2013) asserted that organizational climate is built up through years of certain type of leadership, a certain level of performance, a certain discipline, and possibly, many other factors in an organization. They define organizational climate as the characteristics that distinguish an organization from other organizations and that influence the behavior of people in the organization. Gitonga and Gachunga (2015) defined work environment which synonyms to work climate as being about creating conditions in which an employee can perform his or her duties comfortably. Previous studies had pointed out to the fact there existed a positive correlation between work climate and organizational performance (Ozge \& Altindag, 2016).

\subsection{Employee Engagement}

The way leaders in organizations engage employees denote the culture of that organization and subsequently determines its performance. According to Harvard Business Review (2013), employee engagement has become a top business priority for senior executives since they are aware that a high-performing workforce is essential for growth and survival of organizations. Additionally, a high engaged workforce can increase innovation, productivity and bottom-line performance while reducing costs of hiring and retention in highly competitive talent markets. Patel (2014) defined employee engagement as the emotional connection an employee feels toward his or her employment organization which tends to influence his or her behaviors and level of effort in work related activities. Gikonyo (2018) explained that employee engagement is the opposite of burnout because whereas burnout is characterized by absence of energy and emotional disinterest, engagement is characterized by vigor, dedication and absorption. Employee engagement can therefore be explained as the level at which top leaders in organizations involve their employees in the decision making of the firm. A Harvard Business Review (2013) report that involved executives from all over the world indicated that 71 percent of the executives ranked employee engagement as very important to achieving overall organizational success. Besides, the study further found out that 72 percent of the executives ranked recognition given to high performers as having a significant impact on employee engagement.

\subsection{Staff Reward}

The way employees in an organization are rewarded for the efforts that they put in their work plays an important role in the success of such an organization. As an illustration, Prouska, Psychogios and Rechepi (2016) wrote that although reward strategies had traditionally been based on financial rewards, many businesses are now implementing a "total rewards" approach driven by the rapid cost increase in specific areas of benefits, the 
recognition that employees are as much motivated by nonfinancial factors as by financial packages and by an increased diversification of the workforce. They define the concept of "total rewards" as an approach to employee rewards which incorporates financial rewards as well as other rewarding experiences such as the type of work, work environment, management and leadership style and opportunities for learning and development. Bussin and Thabethe (2018) defined employee rewards as the sum of financial (basic pay, variable pay and employee benefits) and non-financial compensations such as recognition, learning and development opportunities and increased job responsibility paid by the organization to employees in exchange of their services. Indeed, Bange (2013) postulated that reward scheme in an organization refers to all of the monetary, non-monetary and psychological payments that an organization provides for its employees. Previous studies by Kwenin, Muathe and Nzulwa (2013) on the influence of employee rewards, job satisfaction, and human resource policies on employee retention in Vodafone Ghana Limited indicated that job satisfaction and favorable human resource policies significantly impact employee retention and consequently organizational performance.

\subsection{Stakeholder Engagement}

While defining stakeholder engagement, Noe, Hollenbeck, Gerhart and Wright (2010) wrote that they include shareholders, the community, customers, employees and all the other parties that have an interest in seeing that the company succeeds. Additionally, they are the various interested groups who have relationships with, and consequently, whose interests are tied to the organization such as employees, suppliers, customers, shareholders and community. Ayuso, Rodriguez, and GarciaCastro (2012) defined stakeholders as essential for the business itself to exist and have some kind of formal contract with the business such as owners/shareholders, employees, customers and suppliers. Kinyua (2016) defined stakeholder engagement as the process of effectively eliciting stakeholders' views on their relationship with the organization, program, or project. Stakeholder engagement is so important for an organization because without them, it would be difficult such an organization to remain in business. Corner (2015) did a study on stakeholder engagement on organizational performance in New Mexico and Oklahoma and the results indicated that higher levels of collaboration are positively related to perceived improvements in direct substantive outcomes for Native American students.

\section{ORgANIZATIONAL PERFORMANCE}

The ever changing business environment in which firms operate has made organizational performance an important factor to be considered by strategic organizational leaders. According to Gusmao, Christiananta, and Ellitan (2018), organizational performance is the total performance results achieved by an organization in accordance with its vision and mission. Equally important, Samad, Alghafis, and Al-Zuman (2018) defined organizational performance as a multidimensional concept that entails performance in business and organizational effectiveness both in public and private organizations. Likewise, organizational performance is about creating values for the primary beneficiaries of an organization which includes shareholders, employees and the community around the organizations (Agwu, 2018). Kasera (2017) posited that organizational performance is a variable that is used to measure the degree in which an organization is achieving its objectives, efficiency and effectiveness in their goals. Moreover, organizational performance is an indicator to measure the efficiency of an organization to accomplish its objectives in terms of achieving organization market orientation and financial goals.

\section{ORgANIZATIONAL CUlture AND ORGANIZATIONAL PERFORMANCE}

Quite a number of previous studies had been done to determine the effects of organizational culture on performance. For example, a study that was done in Slovenia, Gorenak and Kosir (2012) established a weak correlation between the two variables. Further, Amah and Ahiauzu (2014) did an empirical study to determine the effects of shared values on organizational effectiveness in Nigerian Banks and found a positive relationship between shared values and productivity in the banks studied. In Kenya, Otwori and Juma (2017) did a study to establish the effects of organizational values on employee performance in Urban Roads Authority with the results revealing that there was a significant positive effect of organizational values on employee performance in the organization. A study by Mumo (1997), found out that A.I.C church did not embrace changes and especially in the curriculum used in its theological training institutions.

Previous research studies have been conducted in the past from the global, regionally, and local contexts to determine the effects of work climate/environment on organizational performance. Results of a review of various studies on work climate and employee's performance in Turkey by Ozge and Altindag (2016) found out that work climate that exhibit clear role clarity dimensions result in a higher satisfaction and performance of employees. Correspondingly, in a study conducted in Nigeria, Omolayo, Owolabi, Omole, and Ekundayo (2013) found out that job satisfaction and organization climate does not influence job performance because of the fact that employee's performance on the job is affected by his or her ability and skill as well as a number of situational and environmental factors such as management's leadership style and personnel policies. Additionally, results of a previous study on the influence of work environment on organizational performance in Government Ministries in Kenya, Gitonga and Gachunga (2015) found out that work environment as the most critical factor in keeping an employee satisfied in today's business world.

Empirical studies point out to the fact that there exist a relationship between employee engagement and organizational performance. A systematic review of previous literature by Motyka (2018) discovered how scholars and practitioners had indicated low employee engagement at work as one of the current most alarming global economic problems in Poland with only 15 percent of workers being engaged in their work while 85 percent are not engaged or are actively disengaged. From Nigeria, Abugre (2010) found out that when workers realize that their supervisors are ready to share information with them, the workers will be willing to reciprocate this gesture with better performance in their jobs. In the same way, results of a research study by Aswani (2018) on the effects of performance measurement on employee 
engagement in multinational corporations in Kenya found a strong positive correlations between the two variables.

In previous research studies, employee rewards have been proved to either have a positive or a negative effect on organizational performance. Globally, Aktar, Sachu, and Ali (2012) conducted an empirical study to establish the impact of rewards on employee performance in commercial banks of Bangladesh. The results indicated that there was a statistical significant relationship between employee rewards and organizational performance in the banks studied. In Africa and particularly in Nigeria, Chinyo, Suresh, Salisu (2018) in their study to determine the impacts of monetary rewards on public sector employees in construction companies, the results established that construction employees in Jigawa State's public sector were motivated by salary, allowances, gratuity, and pension. In Kenya, Njanja, Maina, Kibet, and Njagi (2013) did a study on the effects of rewards on employee performance in Kenya Power and Lightning Company Limited in Nakuru. The results of this study indicated that cash bonus had no effect on employee performance because those who received cash bonuses and those who did not all agree that cash bonus affects their performance the same way.

Stakeholders' engagement play a critical role in the success of organizations. In the African Continent, a study on stakeholder perceptions on the impact of reforms on the performance and sustainability of the cotton sector in Ghana and Burkina Faso by Boafo et al (2018) discovered that reforms in Ghana and Burkina Faso took different structural and policy directions and subsequently generated different outcomes to the six performance domains in the study. For example, stakeholders in Ghana perceived predominantly negative outcomes whereas Burkina Faso stakeholders perceived negative and positive outcomes. In a study by on the effect of stakeholder engagement on effectiveness of public universities in Kenya by Kimutai and Kwambai (2018), the results indicated a significant positive relationship between stakeholder engagement and organizational effectiveness in the University of Eldoret due to the fact that stakeholders are involved in the decision making process within the university implementation programs and projects.

\section{METhODOLOGY}

The study adopted descriptive survey research design. Data was collected using closed and open-ended questionnaires from the targeted population of 120 Management, employees and third year students from A.I.C theological training institutions in Kenya. Once collected, the data was cleaned, coded and entered into a SPSS software before it was analysed and results presented. The three A.I.C theological training institutions were selected using purposeful sampling while the Management members, employees and students were selected using stratified random sampling so that only respondents with rich information were included in the study.

\section{RESULTS}

The results indicated that there existed a positive correlation between organizational culture and performance of A.I.C theological training institutions in Kenya at 0.517 as shown in table 1 below. This could imply that organizational performance increases in direct proportion with organizational culture.

\section{Table 1: Correlation analysis - Organizational culture and organizational performance}

\begin{tabular}{llll}
\hline & & $\begin{array}{l}\text { Organizational } \\
\text { Culture }\end{array}$ & Organizational Performance \\
\hline \multirow{2}{*}{ Organizational Culture } & Pearson Correlation & 1 & $.517^{* *}$ \\
& Sig. (2-tailed) & & .000 \\
& $\mathrm{~N}$ & 94 & 94 \\
Organizational Performance & Pearson Correlation & $.517^{* *}$ & 1 \\
& Sig. (2-tailed) & .000 & \\
& $\mathrm{~N}$ & 94 & 94 \\
\hline
\end{tabular}

**. Correlation is significant at the 0.01 level (2-tailed).

Source (Field Data)

Table 4.66: Model summary - Organizational Culture and Organizational Performance

\begin{tabular}{lllll}
\hline Model & $\mathrm{R}$ & R Square & Adjusted R Square & Std. Error of the Estimate \\
\hline 1 & $.517^{\mathrm{a}}$ & .267 & .259 & 7.048 \\
\hline
\end{tabular}

a. Predictors: (Constant), Organizational Culture

Source (Field Data)

Table 4.67: ANOVAa model - Organizational Culture and Organizational Performance

\begin{tabular}{lllllll}
\hline Model & & Sum of Squares & Df & Mean Square & F & Sig. \\
\hline \multirow{3}{*}{1} & Regression & 1662.979 & 1 & 1662.979 & 33.475 & $.000^{\mathrm{b}}$ \\
& Residual & 4570.340 & 92 & 49.678 & & \\
& Total & 6233.319 & 93 & & & \\
\hline
\end{tabular}

a. Dependent Variable: Organizational Performance 


\author{
b. Predictors: (Constant), Organizational Culture \\ Source (Field Data)
}

Table 4.68: Coefficient table - Organizational Culture and Organizational Performance

\begin{tabular}{lllllll}
\hline Model & \multicolumn{2}{c}{ Unstandardized Coefficients } & $\begin{array}{l}\text { Standardized } \\
\text { Coefficients } \\
\text { Beta }\end{array}$ & $\mathrm{t}$ & Sig. \\
& $\mathrm{B}$ & Std. Error & 4.709 & & 5.945 & .000 \\
1 & $\begin{array}{l}\text { (Constant) } \\
\text { Organizational }\end{array}$ & 27.996 & .256 & .517 & 5.786 & .000 \\
\hline
\end{tabular}

a. Dependent Variable: Organizational Performance

Source (Field Data)

The results indicated that the power as explained by the change of the dependent variable (organizational performance) and independent variable (organizational culture) was 0.267 . This therefore meant that 26.7 percent of the organizational performance at the selected three A.I.C theological training institutions was explained by organizational culture with the remaining 73.3 percent being explained by other variables. In terms of the significant of the model, the F-value was found to be relatively significant at 33.475 . Additionally, the results indicated that the correlation coefficient between organizational performance and organizational performance was positive at 0.517.In terms of the effects of organizational culture on organizational performance determined by beta, the results indicated a $\beta$ value of .517 which is a positive effect. This therefore implied that an increase in organizational culture resulted in an increase in organizational performance.

\section{CONCLUSION}

The unpredictable business environment in which organizations are operating in today has made the measurement of performance a necessity and not an option. Further, results of previous studies indicate that many organizations had been facing performance challenges in the hands of leaders who were unable to shape their future and destiny of their organizations through the maintenance of a conducive corporate culture. Some of the aspects of organizational culture are organizational values, policies and procedures, workplace climate, employee engagement, reward system, and stakeholder engagement. And since the results of this study had indicated that organizational culture to a great extent affects performance, it is recommended that leaders take the culture of organizations with the seriousness it deserves.

\section{REFERENCES}

[1] Abugre, J. B. (2010). Essentials of employee communication: Empirical evidence for theoretical and managerial practice. Lambert, Goppingen: GmbH \& Company.

[2] Agwu, M. E. (2015). Lecture note on advanced strategic management. Covenant University, Ota, Ogun State: Unpublished.

[3] Aktar, S., Sachu, M. K., \& Ali, M. D. (2012). The impact of rewards on employee performance in commercial banks of Bangladesh: An empirical study. IOSR Journal of Business and Management, 6(2), 9-15.

[4] Amah, E., \& Ahiauzu, A. (2014). Shared values and organizational effectiveness: A study of the Nigerian banking industry. Journal of Management Development, 33(7), 694-708.
[5] Armstrong, M., \& Taylor, W. T. (2014). Armstrong's handbook of human resource management practice. United Kingdom: Ashford Color Press Limited.

[6] Aswani, J. O. (2018). Effect of performance measurement on employee engagement in multinational corporations in Kenya. (Unpublished doctoral dissertation) Jomo Kenyatta University of Agriculture and Technology, Nairobi, Kenya.

[7] Ayuso, S. A., Rodriguez, M. A., \& Garcia-Castro, R. (2012). Maximizing stakeholders' interests: An empirical analysis of the stakeholder approach to corporate governance. Business and Society, 53(3), 414, 439.

[8] Bange, E. M. (2013). Factors influencing reward at Safaricom Limited. Human Resource Management, 27(6), 25-33.

[9] Boafo, Y. A., Balde, B. S., Saito, O., Gasparatos, A., Damlam, R., Ouedraogo, N., Chamba., \& Moussa, Z Z. P. (2018). Shareholder perceptions of the impact of reforms on the performance and sustainability of the cotton sector in Ghana and Burkina Faso: A tale of two countries. Cogent Food and Agriculture, 2-61. DOI: http://dx.doi.org/10.1080/23311932.2018.1477541.

[10] Bussin, M. H. R., \& Thabethe, N. N. (2018). Reward preferences in South Africa's media industry. South Africa Journal of Human Resource Management, 16(0), a1010.

[11] Chinyo, E., Suresh, S., \& Salisu, J. B. (2018). The impacts of monetary rewards on public sector employees in construction: A case of Jagawa State in Nigeria. Journal of Engineering, Design, and Technology, 16(1)125-142.

[12] Corner, T. W. (2015). Exploring the diverse effects of stakeholder engagement on organizational performance. The American Review of Public Administration, 47(6), 634-647.

[13] Cram, W. A. (2012). Aligning organizational values in systems development projects. Management Research Review, 35(8), 709-726.

[14] Gikonyo, C. S. (2018). Employee engagement and performance of research and training state corporations in Kenya. (Unpublished doctoral dissertation) Kenyatta University, Nairobi, Kenya.

[15] Gitonga, L., \& Gachunga, H. (2015). Influence of work environment on organizational performance in government ministries in Kenya. The Strategic Journal of Business Change and Change Management, 2(83), 1043-1071.

[16] Gorenak, M., Kosir, S. (2012). The importance of organizational values for organization: Management, knowledge, and learning. International Conference, 563-569.

[17] Gunaseelan, B. A. (2012). A study on the impact of work environment on employee performance. Namelex International Journal of Management Research, 71(2), 72-85.

[18] Gusmao, F. D., Christiananta, B., \& Ellitan, L. (2018). The influence of strategic leadership and organizational learning on organizational performance with organizational behaviour as an intervening variable. International Journal of Scientific Research and Management, 6(4), 124-131.

[19] Harvard Business Review Analytic Services Report (2013).The impact of employee engagement on performance. Harvard Business Review, 1-16.

[20] Ivancevich, J.M., Konopake, R., \& Matteson, M. T. (2014). Organizational behavior and management (10th ed.). New York, NY: McGraw-Hill. 
[21] Joyce, P. (2012). Strategic leadership in the public services (2nd ed.). London: Routledge.

[22] Kasera, G. K. (2017). Strategic management and organizational performance: Findings from health institutions in Nairobi County (Unpublished master's thesis) United States International University, Nairobi, Kenya.

[23] Kimutai, K. S., \& Kwambai, M. (2018). Effect of stakeholder engagement on effectiveness of public universities in Kenya: Case of University of Eldoret. International Journal of Economics, Commerce, and Management, 6(2), 524-536.

[24] Kinyua, J. M. (2016). Stakeholder management strategies and financial performance of deposit taking saccos in Kenya (Unpublished doctoral dissertation) Jomo Kenyatta University of Agriculture and Technology; Nairobi, Kenya.

[25] Kumar, N. (2012). Relationship of personal and organizational values with job satisfaction. Journal of Management Research, 12(2), 75-82.

[26] Kwenin, D. O., Muathe, S., \& Nzulwa, R. (2013). The influence of employee rewards, human resource policies, and job satisfaction on the retention pf employees in Vodafone Ghana Limited. European Journal of Business and Management, 5(2), 13-20.

[27] Memon, S. B., Panhwar, A. I., \& Rohra, L. C. (2010). Investigating the mediating role of human resource policies in employee retention. Australian Journal of Basic and Applied Sciences, 4(8), 4046-4057.

[28] Motyka, B. (2018). Employee engagement and performance: A systematic literature review. International Journal of Management and Economics, 54(3), 227-244.

[29] Mumo, P. M. (1997). A study of theological education in Africa Inland Church-Kenya: Its historical development and its present state (Unpublished doctoral dissertation), University of Nairobi, Nairobi, Kenya.

[30] Naidoo, M. (2015). Contested issues in training ministers in South Africa. Stellenbosch. Sun Press.

[31] Naidoo, M. (2016). An ethnographic study on managing diversity in two protestant theological colleges. Theological Studies, 72(1), 1-10.

[32] Ng'ang'a, L. W. (2018). The perceived influence of strategic leadership on organizational performance tourism government agencies in Kenya (Unpublished doctoral dissertation). Kabarak University, Nakuru, Kenya.

[33] Njanja, L. W., Maina, R. N., Kibet, L. K., \& Njagi, K. (2013). Effect of reward on employee performance: A case of Kenya Power and Lightning Company Limited., Nakuru, Kenya. International Journal of Business and Management, 8(21)41-49.

[34] Nkonge, D. (2013). Theological education institutions in Kenya and the future of the church: An Anglican case study. Journal of Adult Theological Education, 10(2), 147-161.

[35] Noe, R. A., Hollenbeck, J. R., Gerhart, B., \& Wright, P. M. (2010). Human resource management: Gaining competitive advantage (7th ed.). Boston: McGraw Hill.

[36] Omolayo, B. O., Owolabi, A. B., Omole, O. C., Ekundayo, K. D. (2013). Influence of job satisfaction and organization work climate on job performance. Scottish Journal of Arts, Social Sciences, and Scientific Studies, 10(1), 39-50.
[37] Otwori, N. L., Juma, D. (2017). Effect of organizational values on employee performance: A case of Urban Roads Authority. International Journal of Science and Research (IJSR), 6(6), 100-104.

[38] Ozge, A., \& Altindag, E. (2016). The effects of reengineering, organizational climate, and psychological capital on the firm performance. 12th International Strategic Management Conference, Turkey, Procedia. Social and Behavioral Sciences, 235(1), 320-331.

[39] Patel, S. (2014). Race and employee engagement in a diversified South African retail group (Unpublished master's thesis). University of the Western Cape, Cape Town, South Africa.

[40] Prouska, R., Psychogios, A. G., \& Rexhepi, Y. (2016). Rewarding employees in turbulent economies for improved organizational performance: Exploring SMEs in the South-Eastern European region. Personnel Review, 45(6), 1259-1280.

[41] Quenneville, N., Bentein, K., \& Simard, G. (2010). From organizational values to mobilization of human resources. Canadian Journal of Administrative Sciences, 27(2), 122-135.

[42] Samad, S., Alghafis, R., \& Al-Zuman, A. (2018). Examining the effects of strategic leadership and organizational culture on organizational performance. Management Science Letters, 8(12), 1363-1374.

[43] Suar, D., \& Khuntia, R. (2010). Influence of personal values and value congruence on unethical practices and work behavior. Journal of Business Ethics, 97(3), 443-460.

[44] Sudarsanam, S. (2010). Creating values from mergers and acquisition. United Kingdom: Pearson Education Limited.

[45] Volberda, H. W., Morgan, R. E., Reinmoeller, P., Hitt, M. A., Ireland, R. D., \& Hoskisson, R. E. (2011). Strategic management: Competitiveness and globalization. Singapore: Brendan George.

[46] Wolosz, L. (2007). Sound policies and procedures: The basis for a sound compliance program. Journal of Investment and Compliance, 8(4), 7 11 .

\section{AUTHORS}

First Author - Munyao, Solomon. M, School of Leadership, Business and Technology, Pan Africa Christian University, P.O. Box 56875-00200, Nairobi

Second Author - Chiroma, Nathan. H. (PhD), School of Theology, Pan Africa Christian University, P.O. Box 5687500200, Nairobi

Third Author - Ongeti, Walter. J. (PhD), School of Leadership, Business and Technology, Pan Africa Christian University, P.O. Box 56875-00200, Nairobi

\section{Email of corresponding author}

solomon.munyao@pacuniversity.ac.ke 